\title{
Status of N-of-1 Trials in Chronic Pain Management: A Narrative Review
}

\author{
Wanying He $\cdot$ Zichan Cui $\cdot$ Yin Chen $\cdot$ Fang Wang $\cdot$ Fengxian Li (D
}

Received: July 11, 2021 / Accepted: August 26, 2021 / Published online: September 16, 2021

(C) The Author(s) 2021

\begin{abstract}
N-of- 1 trials are randomized controlled clinical trials conducted exclusively on a single patient. The ultimate aim of N-of- 1 trials is to optimize a strategy in a particular individual. Chronic pain is a common but refractory clinical problem. Its diverse etiologies and broad variations among patients often lead to the requirement of individualizing medicine. Thus, chronic pain represents a classical condition for N-of- 1 clinical trials. Studies have indicated that N-of-1
\end{abstract}

Wanying He and Zichan Cui contributed equally to this work.

W. He · Z. Cui · Y. Chen · F. Li $(\bowtie)$

Department of Anesthesiology, Zhujiang Hospital, Southern Medical University, No. 253 Gongye Road, Guangzhou 510282, China

e-mail: lifengxian81@smu.edu.cn

W. He

e-mail: DrHewanying@outlook.com

Z. Cui

e-mail: cherrys_324@163.com

Y. Chen

e-mail: bacterium_chen@163.com

F. Wang

Department of Dermatology, The First Affiliated Hospital, Sun Yat-Sen University, 58 Zhongshan Er Road, Guangzhou 510080, China

e-mail: wangf78@mail.sysu.edu.cn benefits patients with chronic pain, multiple comorbidities, and uncertain variations during therapies; however, this approach it is not yet adopted as the first choice in pain clinics. To dissect the current status of N-of- 1 in chronic pain management, as well as the limitations for its implementation, we herein studied all N-of-1 studies related to chronic pain by searching three major databases (PubMed, ClinicalTrial.gov, Cochrane Library) for publications between 1985 and 2020. Of 35 eligibility papers, 19 were selected for analysis. Results confirmed that N-of-1 trials have solved the refractory cases including osteoarthritis, chronic musculoskeletal pain, and neuropathic pain; however, none of the trials dealt with cancer pain. Longer time and more efforts are needed from investigators when carrying out N-of-1 trials, which inevitably result in implementation difficulties. Of note, all recruited trials were conducted in developed countries. As mobile devices have been introduced and protocols improve, renewed interest in the implementation of N-of1 trials will occur. Collectively, a previously underestimated conflict between "precision medicine" and "poor implementation" has put $\mathrm{N}$-of-1 in a challenging position for chronic pain management.

Keywords: N-of-1; Chronic pain; Single patient trial; Precision medicine 


\section{Key Summary Points}

N-of- 1 trials have potential roles in solving the refractory cases of chronic pain.

$\mathrm{N}$-of-1 trials in chronic pain are not so popular nowadays.

$\mathrm{N}$-of-1 trials for chronic pain were not well conducted in developing countries.

\section{INTRODUCTION}

Chronic pain is an intractable and debilitating condition which is defined as pain that lasts beyond "normal healing". A variety of pathologic conditions such as osteoarthritis and cancer can present with chronic pain. Chronic pain severely impairs quality of life of patients and has become one of the leading causes for seeking medical care [1]. However, as a result of the broad spectrum of etiology, the same medication often reveals inconsistent pain-relief effects among different patients. Thus, the provision of effective and individualized treatment to patients suffering from chronic pain is of great significance in clinical practice.

$\mathrm{N}$-of-1 or single subject clinical trials are randomized controlled crossover trials in a single patient and investigate the efficacy or side effects of different interventions. The goal of an $\mathrm{N}$-of-1 trial is to determine the optimal intervention for an individual patient using objective data-driven criteria. Given that N-of- 1 trials are capable of solving the uncertainty induced by heterogeneous treatment effects across diverse patients, chronic pathologic conditions like chronic pain are excellent indications for $\mathrm{N}$-of-1 trials.

The first N-of-1 trial for chronic pain was carried out in 1994 [2, 3]. In 2010, guidance for conducting N-of- 1 trials was published (CENT 2015) [4]. Later in 2015, Consolidated Standards of Reporting Trials (CONSORT) extended the guidance for N-of-1 trials (CENT 2015) [4]. Nowadays, CENT provides 14 of the 25 items of the CONSORT checklist and recommends a diagram for depicting an individual N-of-1 trial. However, despite the progress in methodological standards, N-of- 1 trials seem not to have been widely applied in chronic pain treatment compared to other classic clinical trials. We therefore hypothesized that N-of-1 trials may have some hurdles, rather than inefficiency, that limit their applications in verifying drug efficacy for patients with chronic pain. To explore this, we reviewed publicly available clinical trials from 1985 to 2020 . Focusing on 19 studies that met our inclusion criteria, we found that N-of-1 trials indeed demonstrated their capacity in patients with diverse chronic pain causes. However, all N-of-1 trials have significant regionality. We describe the current status of these trials and delineate their different clinical settings. After analyzing the influences on implementation of N-of- 1 trials for chronic pain cases around the world, we then discuss the trends and difficulties in implying N-of- 1 in special cases and developing countries. Finally, we propose a prospective future framework for $\mathrm{N}$-of-1 trials in chronic pain treatments.

\section{METHODS}

\section{Search Strategy}

We conducted a review of N-of- 1 clinical trials published from 1985 to 2020 in journals indexed by PubMed and Cochrane Library. We also searched for unpublished studies on the ClinicalTrials.gov website. The search strategy used included the following terms shown in either title or abstract: chronic pain, N-of-1, single-case trial, single-subject research, single case experimental design, single-patient study, single patient trials, single-case trials, and single-patient trial. We defined an N-of-1 as a prospective, multiple-period, crossover study conducted on a single patient. Chronic pain was defined as pain that persists or recurs for longer than 3 months. The protocol for this review was developed on the basis of the PRISMA statement. The PRISMA checklist can be found in Supplementary material 1. This article is based on previously conducted studies 
and does not contain any new studies with human participants or animals performed by any of the authors.

\section{Eligibility Criteria}

N-of-1 trials that meet the following criteria were included into this study: (1) Trials were conducted on humans. (2) Involve randomization of treatments within blocks or pairs, crossover of interventions, individual patients or series of patients, and single patients as the unit of analysis. (3) Pharmacological interventions were evaluated. (4) Trials that had the following information: trial purpose, cohort number, completion rate, individual outcomes, and post-trial completion decision. (5) Patients enrolled had chronic pain.

\section{Information Sources and Searches}

The corresponding authors (Fengxian Li) performed literature searching and imported results into EndNote 8 software, in which duplicates were removed. Four researchers (Wanying He, Zichan Cui, Fang Wang, and Yin Chen) screened the titles and abstracts of remaining publications independently. Studies that did not meet the inclusion criteria for title and abstract were excluded. Full-text articles were then assessed to decide which studies could be included for further qualitative synthesis. Any disagreements were resolved through discussion among all authors.

\section{Data Extraction and Synthesis}

The data extracted from each article included design, participants, disease, type of intervention, outcomes, washout, blinding, withdrawal rate, and the corresponding author's country. This process was independently performed by two researchers.

The quality assessment identified risk bias according to the CENT 2015 statement and Cochrane handbook for systematic reviews of intervention as shown in Table 1 (1. Selection bias? 2. Reporting bias? 3. Performance bias? 4. Inadequate cycle? (Risks of error-especially type 2) 5. Appropriateness of treatment for design? 6. Appropriate washout period?).

The goal of the review was to summarize the development and current status of N-of- 1 trials in chronic pain management. N-of- 1 trials have the advantage of effectively conducting a metaanalysis on their own. For this reason, we did not conduct a meta-analysis here.

\section{RESULTS}

Overall, 505 titles were found by our systematic search. Further search in related references added 14 additional studies. After removal of the duplicates, the abstracts of 369 published articles were reviewed to determine articles within the scope of our criteria. The study selection approach and the number of publications obtained are shown in Fig. 1. From these studies, 35 articles were selected for the full-text assessment of eligibility, and the remaining articles were excluded for being off-topic. Among those 35 articles, three were considered as one because of the replicated registration on ClinicalTrials.gov (Identifier NCT02116621) $[20,22,23]$. Finally, 19 articles fulfilled the inclusion criteria and were retained for this narrative review. Characteristics and synthesis of these studies are displayed in Table 2.

\section{Development of N-of-1 in Chronic Pain Management}

Of the 19 articles we analyzed, the earliest two $\mathrm{N}$-of-1 studies for chronic pain were published in 1994, which was 8 years later than the first formal definition of N-of-1 trial was proposed by Guyatt et al. [25] (Fig. 2). The two patients reported in studies published in 1994 respectively had osteoarthritis and neuropathic pain $[2,3]$.

From 1994 to now, it appears that different distribution patterns of N-of- 1 trials in chronic pain management have emerged (Figs. 2, 3):

First, from 1994 to 2004, N-of-1 has been introduced. During this period, clinicians explored the feasibility of N-of-1 in chronic pain management. Small cohorts (8-30 patients per study) were used to determine better drugs 
Table 1 Quality assessment of studies included

\begin{tabular}{|c|c|c|c|c|c|c|}
\hline $\begin{array}{l}\text { First } \\
\text { author, } \\
\text { (year) }\end{array}$ & $\begin{array}{l}\text { Selection } \\
\text { bias }\end{array}$ & $\begin{array}{l}\text { Reporting } \\
\text { bias }\end{array}$ & $\begin{array}{l}\text { Performance } \\
\text { bias }\end{array}$ & $\begin{array}{l}\text { Inadequate cycle (risk } \\
\text { of error-especially } \\
\text { type } 2 \text { ) }\end{array}$ & $\begin{array}{l}\text { Appropriateness of } \\
\text { treatment for } \\
\text { design }\end{array}$ & $\begin{array}{l}\text { Appropriate } \\
\text { washout } \\
\text { period }\end{array}$ \\
\hline $\begin{array}{c}\text { McQuay, } \\
\text { (1994) } \\
{[3]}\end{array}$ & High $^{a}$ & Low & Low & High & Low & Unclear \\
\hline $\begin{array}{l}\text { March, } \\
\qquad(1994) \\
{[2]}\end{array}$ & Low & Low & Low & Low & Low & High \\
\hline $\begin{array}{l}\text { Paice, } \\
\qquad(1996) \\
{[5]}\end{array}$ & High & Low & Low & Low & Low & Unclear \\
\hline $\begin{array}{c}\text { Sheather- } \\
\text { Reid, } \\
(1998) \\
{[6]}\end{array}$ & Low & Low & High & Low & Low & High \\
\hline $\begin{array}{l}\text { Haines, } \\
\qquad(1996) \\
{[7]}\end{array}$ & High & Unclear & Low & Low & Low & Unclear \\
\hline $\begin{array}{l}\text { Nikles, } \\
\qquad(2000) \\
{[8]}\end{array}$ & Low & Low & Low & Low & Low & High \\
\hline $\begin{array}{l}\text { Wegman, } \\
(2003) \\
{[9]}\end{array}$ & Unclear & Low & Low & Low & low & High \\
\hline $\begin{array}{l}\text { Notcutt, } \\
\qquad \begin{array}{l}(2004) \\
{[10]}\end{array}\end{array}$ & Low & Low & Low & High & Low & High \\
\hline $\begin{array}{l}\text { Green, } \\
\qquad(2004) \\
{[11]}\end{array}$ & Low & Low & low & Low & high & Unclear \\
\hline $\begin{array}{l}\text { Pope, } \\
\qquad(2004) \\
{[12]}\end{array}$ & Low & Unclear & Low & Unclear & Low & Low \\
\hline $\begin{array}{l}\text { Nikles, } \\
\qquad(2005) \\
{[13]}\end{array}$ & Low & Low & Low & Low & Low & Low \\
\hline $\begin{array}{l}\text { Nikles, } \\
\qquad(2005) \\
{[14]}\end{array}$ & Low & Low & Unclear & Unclear & Low & Unclear \\
\hline
\end{tabular}


Table 1 continued

\begin{tabular}{|c|c|c|c|c|c|c|}
\hline $\begin{array}{l}\text { First } \\
\text { author, } \\
\text { (year) }\end{array}$ & $\begin{array}{l}\text { Selection } \\
\text { bias }\end{array}$ & $\begin{array}{l}\text { Reporting } \\
\text { bias }\end{array}$ & $\begin{array}{l}\text { Performance } \\
\text { bias }\end{array}$ & $\begin{array}{l}\text { Inadequate cycle (risk } \\
\text { of error-especially } \\
\text { type 2) }\end{array}$ & $\begin{array}{l}\text { Appropriateness of } \\
\text { treatment for } \\
\text { design }\end{array}$ & $\begin{array}{l}\text { Appropriate } \\
\text { washout } \\
\text { period }\end{array}$ \\
\hline $\begin{array}{l}\text { Huber, } \\
\qquad(2007) \\
{[15]}\end{array}$ & Low & Unclear & Low & Low & Low & Low \\
\hline $\begin{array}{l}\text { Yelland, } \\
\qquad(2007) \\
{[16]}\end{array}$ & Low & Low & Low & Low & Low & Unclear \\
\hline $\begin{array}{l}\text { Yelland, } \\
\qquad(2009) \\
{[17]}\end{array}$ & Low & Low & Low & Low & Low & Low \\
\hline $\begin{array}{l}\text { Nixdorf, } \\
\qquad(2012) \\
{[18]}\end{array}$ & Low & Low & Low & Low & Low & Low \\
\hline $\begin{array}{l}\text { Germini, } \\
\qquad(2017) \\
{[19]}\end{array}$ & Low & Low & Low & Low & Low & Low \\
\hline $\begin{array}{l}\text { Odineal, } \\
\qquad(2019) \\
{[20]}\end{array}$ & Low & Low & Low & Low & Unclear & Low \\
\hline $\begin{array}{l}\text { Lee (2020), } \\
{[21]}\end{array}$ & Low & Low & Unclear & Low & Low & Unclear \\
\hline
\end{tabular}

${ }^{a}$ Level of risk

or test new drugs for an individual patient [2, 7-9]. Clinicians started to use N-of-1 trials to evaluate side effects of existing strategies to treat patients with chronic pain. For example, hemorrhage of the digestive tract caused by non-steroidal anti-inflammatory drugs was assessed [9]. Of note, washout periods are strategies to exclude the residual effects of the test drugs during multiple treatments; however, some trials did not mention their usage at this exploratory stage $[5,6]$.

From 2004, the development of statistical methodology brought N-of-1 trials into a new phase [12]. By that time, reliability had been confirmed by using Bayesian meta-analysis of multiple N-of-1 trials. For example, more practical information was generated from six trials done in patients with juvenile idiopathic arthritis [15]. The book Design and Implementation of N-of-1 Trials: A User's Guide was published in 2012 to further clarify the criteria for conducting such trials. Of note, most N-of- 1 trials in chronic pain management were carried out during this stage.

Afterwards, the CONSORT extension statement for conducting N-of- 1 trials was published in 2015, which provides detailed guidance on the reporting [4]. Thus, the process of N-of-1 trials in chronic pain management was optimized. Importantly, like classical randomized controlled trials (RCTs), N-of- 1 trials started to employ mobile phone apps such as Trialist to 


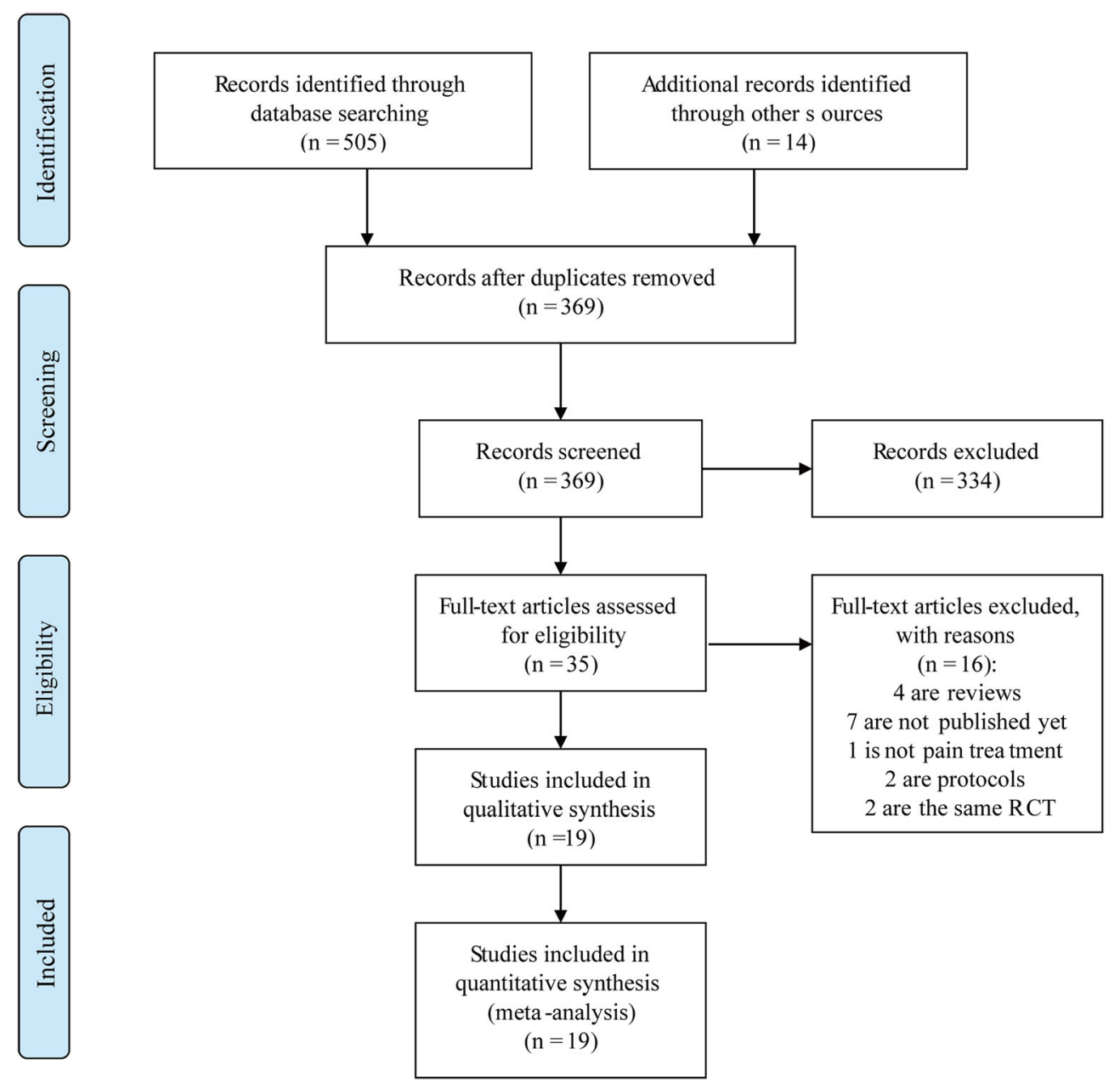

Fig. 1 Flow diagram of screening and inclusion of relevant articles

help with the trial process during this period [20-22]. Particularly, in regard to chronic pain, those mobile apps also exhibited marked benefits in doing N-of-1 trials $[19,23,26]$. Notwithstanding this, the implementation of N-of-1 trials in pain clinic declined, and only three trials from our search list were conducted after $2015[19,21,22]$. To date, the largest N-of- 1 trial was conducted in 2018 (NCT02116621). In this trial, Trialist was used to collect information efficiently [22]. Specifically, the Trialist app not only sent patients the treatment reminder but also recorded the information like pain severity and side effects of the tested drug. By using the Trialist app, clinicians could more efficiently complete the N-of-1 trial and were able to review the trial results and discuss a long-term treatment plan with patients.

\section{Efficiency of N-of-1 in Treating Chronic Pain}

The development of N-of- 1 in chronic pain management benefits some refractory cases (Fig. 4). Briefly, out of the 19 trials identified, $37 \%(7 / 19)$ were searching for treatments for osteoarthritis $\quad(N=245 \quad$ patients $)$ [2, 8, 9, 12-14, 16]. Chronic musculoskeletal pain was identified in $21 \%$ of trials $(4 / 19$; $N=275$ patients) $[6,19,20,22]$ while treatment for neuropathic pain was tested in $21 \%$ of trials $(4 / 19 ; N=115$ patients) $[3,11,17,24]$. Of note, it appears that cancer pain is not a targeted 
Table 2 Characteristics of included N-of- 1 trials for chronic pain treatment

\begin{tabular}{|c|c|c|c|c|c|}
\hline $\begin{array}{l}\text { First author, } \\
\text { (country) } \\
\text { Year, Ref }\end{array}$ & Disease & $\begin{array}{l}\text { Participants } \\
\text { (n) }\end{array}$ & $\begin{array}{l}\text { Intervention } \\
\text { (control) }\end{array}$ & $\begin{array}{l}\text { Withdrawal } \\
\text { rate }\end{array}$ & Conclusion \\
\hline $\begin{array}{l}\text { McQuay, (UK) } \\
1994 \text { [3] }\end{array}$ & Neuropathic pain & 19 & $\begin{array}{l}\text { Dextromethorphan } \\
\text { (placebo) }\end{array}$ & $36 \%$ & $\begin{array}{l}5 \text { patients chose } \\
\text { dextromethorphan after } \\
\text { N-of-1 }\end{array}$ \\
\hline $\begin{array}{l}\text { March, } \\
\text { (Australia) } \\
1994 \text { [2] }\end{array}$ & $\begin{array}{l}\text { Osteoarthritis } \\
\text { pain }\end{array}$ & 20 & $\begin{array}{r}\text { Paracetamol } \\
\text { (NSAIDs) }\end{array}$ & $40 \%$ & $\begin{array}{l}\text { NSAIDs may as good as } \\
\text { paracetamol }\end{array}$ \\
\hline $\begin{array}{c}\text { Paice, (USA) } \\
1996[5]\end{array}$ & $\begin{array}{l}\text { Severe back } \\
\text { pain/multiple } \\
\text { sclerosis }\end{array}$ & 2 & Octreotide $(/)$ & $\mathrm{NA}$ & Pain relief for two patients \\
\hline $\begin{array}{l}\text { Sheather, } \\
\text { (Australia) } \\
1998[6]\end{array}$ & $\begin{array}{l}\text { Chronic } \\
\text { musculoskeletal } \\
\text { pain }\end{array}$ & 5 & $\begin{array}{l}\text { Ibuprofen or } \\
\text { codeine (placebo) }\end{array}$ & $37 \%$ & $\begin{array}{l}\text { Neither ibuprofen nor } \\
\text { codeine shown to exert } \\
\text { analgesic effect }\end{array}$ \\
\hline $\begin{array}{c}\text { Haines, (UK) } \\
1999[7]\end{array}$ & Chronic pain & 21 & $\begin{array}{l}\text { Orally administered } \\
\text { ketamine (usual } \\
\text { treatments) }\end{array}$ & $14 \%$ & $\begin{array}{l}3 \text { patients responded to oral } \\
\text { ketamine administration }\end{array}$ \\
\hline $\begin{array}{l}\text { Nikles, } \\
\text { (Australia) } \\
2000[8]\end{array}$ & Osteoarthritis & 8 & $\begin{array}{l}\text { Paracetamol } \\
\text { (ibuprofen) }\end{array}$ & $43 \%$ & 1 patient preferred NSAIDs \\
\hline $\begin{array}{l}\text { Wegman, } \\
\text { (Netherlands) } \\
2003 \text { [9] }\end{array}$ & Osteoarthritis & 13 & $\begin{array}{r}\text { Paracetamol } \\
\text { (NSAIDs) }\end{array}$ & $46 \%$ & $\begin{array}{l}7 \text { patients chose NSAIDS } \\
\text { and } 6 \text { patients chose } \\
\text { paracetamol after N-of- } 1\end{array}$ \\
\hline $\begin{array}{l}\text { Notcutt, (UK) } \\
2004[24]\end{array}$ & $\begin{array}{l}\text { Chronic pain } \\
\text { (mainly } \\
\text { neuropathic) }\end{array}$ & 34 & $\begin{array}{l}\text { CBME/THC, } \\
\text { CBD, or both } \\
(1: 1) \text { (placebo) }\end{array}$ & $5 \%$ & $\begin{array}{l}28 \text { patients responded to } \\
\text { CBME: } 11 \text { to THC/CBD, } \\
14 \text { to THC and THC/ } \\
\text { CBD equally, } 2 \text { to THC, } 1 \\
\text { THC and CBD equally }\end{array}$ \\
\hline $\begin{array}{l}\text { Green, (UK) } \\
2004[11]\end{array}$ & Neuropathic pain & 7 & DBS on (DBS off) & $\mathrm{NA}$ & $\begin{array}{l}6 \text { patients' VAS reduced. } 4 \\
\text { patients' MPS reduced }\end{array}$ \\
\hline $\begin{array}{l}\text { Pope, (Canada) } \\
2004 \text { [12] }\end{array}$ & Osteoarthritis & 51 & $\begin{array}{l}\text { N-of-1: diclofenac } \\
50 \mathrm{mg} \\
\text { (conventional } \\
\text { treatment) }\end{array}$ & $20 \%$ & $\begin{array}{l}11 \text { out of } 24 \text { patients chose } \\
\text { diclofenac after } \mathrm{N} \text {-of- } 1 \\
\mathrm{~N} \text {-of- } 1 \text { trials cost more than } \\
\text { usual care }\end{array}$ \\
\hline $\begin{array}{l}\text { Nikles, } \\
\text { (Australia) } \\
2005[13]\end{array}$ & $\begin{array}{l}\text { Osteoarthritis and } \\
\text { chronic pain }\end{array}$ & 71 & $\begin{array}{l}\text { NSAIDS or COX-2 } \\
\text { inhibitor or } \\
\text { paracetamol } \\
\text { (placebo) }\end{array}$ & $39 \%$ & $\begin{array}{l}46 \text { patients changed their } \\
\text { management after N-of- } 1\end{array}$ \\
\hline
\end{tabular}


Table 2 continued

\begin{tabular}{|c|c|c|c|c|c|}
\hline $\begin{array}{l}\text { First author, } \\
\text { (country)Year, } \\
\text { Ref }\end{array}$ & Disease & $\begin{array}{l}\text { Participants } \\
(n)\end{array}$ & $\begin{array}{l}\text { Intervention } \\
\text { (control) }\end{array}$ & $\begin{array}{l}\text { Withdrawal } \\
\text { rate }\end{array}$ & Conclusion \\
\hline $\begin{array}{l}\text { Nikles, } \\
\text { (Australia) } \\
2005[14]\end{array}$ & Osteoarthritis & 41 & $\begin{array}{l}\text { Paracetamol } \\
\text { (ibuprofen) }\end{array}$ & $33 \%$ & $\begin{array}{l}\text { Patients satisfied with } \mathrm{N} \text {-of- } 1 \\
\text { trials }\end{array}$ \\
\hline $\begin{array}{l}\text { Huber, } \\
\qquad \text { (Canada) } \\
2007[15]\end{array}$ & JIA & 6 & $\begin{array}{l}\text { Amitriptyline } \\
\text { (placebo) }\end{array}$ & $33 \%$ & $\begin{array}{l}\text { Bayesian techniques could be } \\
\text { used in N-of-1 }\end{array}$ \\
\hline $\begin{array}{l}\text { Yelland, } \\
\text { (Australia) } \\
2007[16]\end{array}$ & Osteoarthritis & 41 & $\begin{array}{l}\text { SR-paracetamol } \\
\text { (celecoxib) }\end{array}$ & $30 \%$ & $\begin{array}{l}7 \text { patients responded to } \\
\text { celecoxib. One patient } \\
\text { responded to SR- } \\
\text { paracetamol } \\
33 \text { patients responded } \\
\text { equally } \\
25 \text { patients continued their } \\
\text { pain management } \\
\text { according to } N \text {-of-1 }\end{array}$ \\
\hline $\begin{array}{l}\text { Yelland, } \\
\text { (Australia) } \\
2009[17]\end{array}$ & $\begin{array}{l}\text { Chronic } \\
\text { neuropathic } \\
\text { pain }\end{array}$ & 55 & $\begin{array}{r}\text { Gabapentin } \\
\text { (placebo) }\end{array}$ & $35 \%$ & $\begin{array}{l}16 \text { patients responded to } \\
\text { gabapentin and } 15 \\
\text { continued gabapentin after } \\
\mathrm{N} \text {-of- } 1\end{array}$ \\
\hline $\begin{array}{l}\text { Nixdorf, (USA) } \\
2012[18]\end{array}$ & $\begin{array}{l}\text { Sympathetic } \\
\text { independent } \\
\text { pain-diagnosis }\end{array}$ & $\begin{array}{l}1 \\
\text { Case report }\end{array}$ & $\begin{array}{l}\text { Lidocaine or stellate } \\
\text { ganglion block } \\
\text { (saline) }\end{array}$ & NA & $\begin{array}{l}\text { The patients had no } \\
\text { response to stellate } \\
\text { ganglion block }\end{array}$ \\
\hline $\begin{array}{l}\text { Germini, (Italy) } \\
2017[19]\end{array}$ & $\begin{array}{l}\text { Chronic pain- } \\
\text { back, joints, } \\
\text { limbs-alone or } \\
\text { combined }\end{array}$ & 10 & Um-PEA (placebo) & $30 \%$ & $\begin{array}{l}4 \text { patients chose um-PEA } \\
\text { after N-of-1 }\end{array}$ \\
\hline $\begin{array}{l}\text { Odineal, (USA) } \\
2019[20]\end{array}$ & $\begin{array}{l}\text { Chronic } \\
\text { musculoskeletal } \\
\text { pain }\end{array}$ & 215 & $\begin{array}{l}\mathrm{N} \text {-of-1 intervention } \\
\quad \text { (usual care) }\end{array}$ & $23 \%$ & $\begin{array}{l}86 \text { out of } 108 \text { patients } \\
\text { thought mHealth APP } \\
\text { helped them manage their } \\
\text { pain } \\
\text { No difference in pain relief } \\
\text { between N-of- } 1 \text { and usual } \\
\text { care }\end{array}$ \\
\hline
\end{tabular}


Table 2 continued

\begin{tabular}{llllll}
\hline $\begin{array}{l}\text { First author, } \\
\text { (country)Year, } \\
\text { Ref }\end{array}$ & Disease & $\begin{array}{l}\text { Participants } \\
(\boldsymbol{n})\end{array}$ & $\begin{array}{l}\text { Intervention } \\
\text { (control) }\end{array}$ & $\begin{array}{l}\text { Withdrawal } \\
\text { rate }\end{array}$ & Conclusion \\
\hline $\begin{array}{l}\text { Lee, }(\mathrm{UK}) 2020 \\
{[21]}\end{array}$ & JIA & 14 & $\begin{array}{l}\text { MHealth } \\
\text { assessment }(/)\end{array}$ & $14 \%$ & $\begin{array}{c}\text { Once-a-day reporting is } \\
\text { enough }\end{array}$ \\
\hline
\end{tabular}

UK United Kingdom, USA United States, JIA juvenile idiopathic arthritis, CMBE cannabis-based medicinal extracts, THC tetrahydrocannabinol, $C B D$ cannabidiol, $D B S$ deep brain stimulation, NSAIDs non-steroidal anti-inflammatory drug, um$P E A$ ultra-micronized palmitoylethanolamide, $V A S$ visual analog scale, $M P S$ McGill pain scores, $N A$ not available

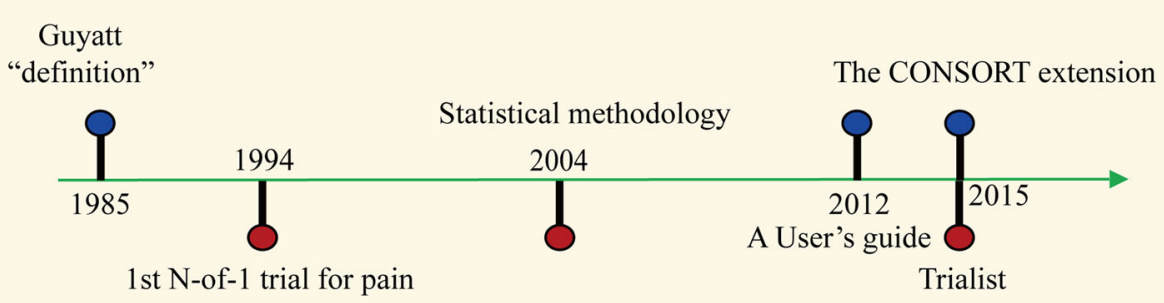

Fig. 2 General development axis of $\mathrm{N}$-of-1 in chronic pain management

disease in any N-of- 1 trials that could be found by our search strategy.

According to the study types of the trials, the identified studies were further divided into analgesics versus placebo $[3,6,7,13,15$, 17-19, 24], analgesics "A" versus analgesics "B" (no placebo) $[, 2,8,9,14,16]$, and N-of-1 trial versus usual care $[12,20,22]$. One classical N-of1 trial was conducted to compare the efficacy of sustained-release (SR) paracetamol with celecoxib [16]. The result indicated that although celecoxib showed better pain relief scores on average, in 33 of 41 patients, no difference between SR paracetamol and celecoxib was identified. Among those 33 patients, 13 decided to manage with SR paracetamol and 6 with celecoxib, while 3 patients switched to nonsteroidal anti-inflammatory drug (NSAIDs). This study has suggested that N-of-1 trials may provide a rational and effective way to identify the optimal treatment.

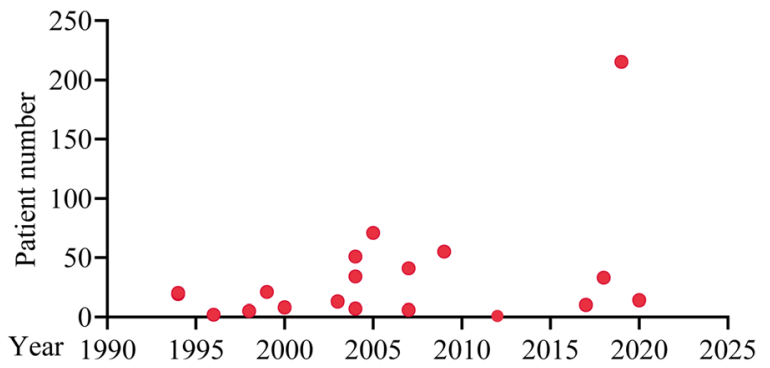

Fig. 3 Yearly distribution and number of patients recruited in $\mathrm{N}$-of-1 trials in chronic pain management

\section{Cost-Benefit Ratio for Conducting N-of-1 Trials in Chronic Pain Management}

As N-of-1 requires plenty of time and great effort to collect all the information before the final decision, clinicians began to improve the cost-benefit ratio and urged researchers to search for a better way to conduct future N-of-1 studies $[27,28]$. In an N-of-1 study conducted by Pope et al., the efficacy of diclofenac 


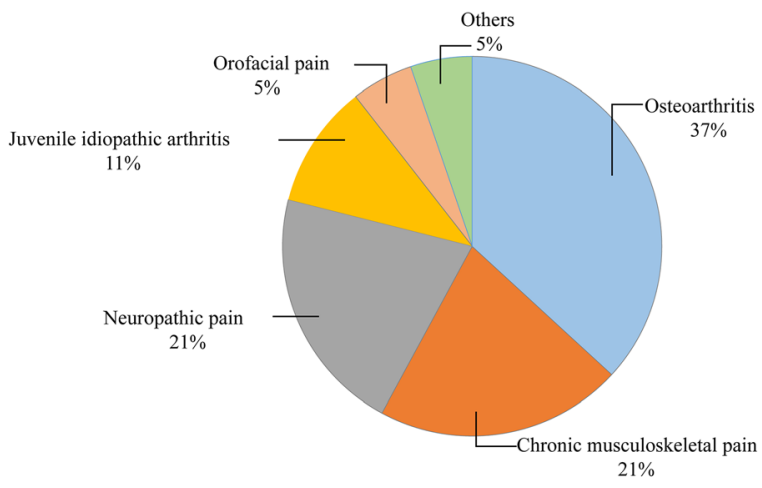

Fig. 4 Disease catalogs benefit from N-of-1 trials

treatment was assessed in patients with osteoarthritis [12]. The results showed that the total osteoarthritis-related cost was Canadian $\$ 551.66 \pm 154.02$ per N-of-1 treated patient (1996 patients in total) in 6 months, while standard procedures cost Canadian $\$ 395.62 \pm 226.87 \quad(p<0.009) \quad[12]$. Of note, there were no significant between-group difference regarding the overall outcome measurements. This study suggests that N-of- 1 trials may need more financial support for conducting trial procedures, follow-up visits, and data analysis. Interestingly, Scuffham et al. also analyzed two previous clinical trials $[16,17]$ and found that N-of- 1 trials could actually save total costs $[27,28]$. They figured out that the annual post-trial costs were significantly lower than pre-trial costs for osteoarthritis (568.42 versus 813.75 Australian dollars) and neuropathic pain (1753.12 versus 1950.58 Australian dollars) when excluding the costs for running the N-of-1 trials, which amounted to 600 Australian dollars. This estimation suggested that although implementation of N-of-1 itself requires extra cost, after the trial, it could save more for longterm treatment without further medical interventions.

\section{Diversity of Geographic Distribution of N- of-1 Trials}

Strikingly, all of the 19 N-of- 1 trials were conducted in developed countries including the USA $(n=3) \quad[5,18,20], \quad$ UK $\quad(n=5) \quad[$, $3,7,11,21,24]$, Italy $(n=1)$ [19], Australia $(n=7)[2,6,8,13,14,16,17]$, Canada $(n=2)$ $[12,15]$, and the Netherlands $(n=1)$ [9]. None of them were conducted in developing countries (Fig. 5).

\section{Limitations for N-of-1 Trials in Chronic Pain Management}

Several limitations regarding conducting N-of-1 trials have been found in our study. The withdrawal rate (Table 2) in N-of-1 trials is about $30 \%$. This is comparable with regular clinical trials [29]; however, the withdrawal rate has a closer relationship with the side effects of drugs but not the N-of-1 trial itself [14].

Second, N-of- 1 trials require a washout period to counteract the residual effects of the drug, especially when using a placebo in the control group. It is difficult to design a washout period perfectly, because the effect of the drug may extend to the placebo stage, which would cause a deviation for the results [15].

Lastly, although a large clinical trial (NCT02116621, three articles were identified from this trial registration) suggested that the Trialist app can help patients manage their pain and reduce the demand for long-term analgesics $[20,22]$, as a result of the differences in medical systems around the world, it would still be difficult to install the same app and strategy in different countries.

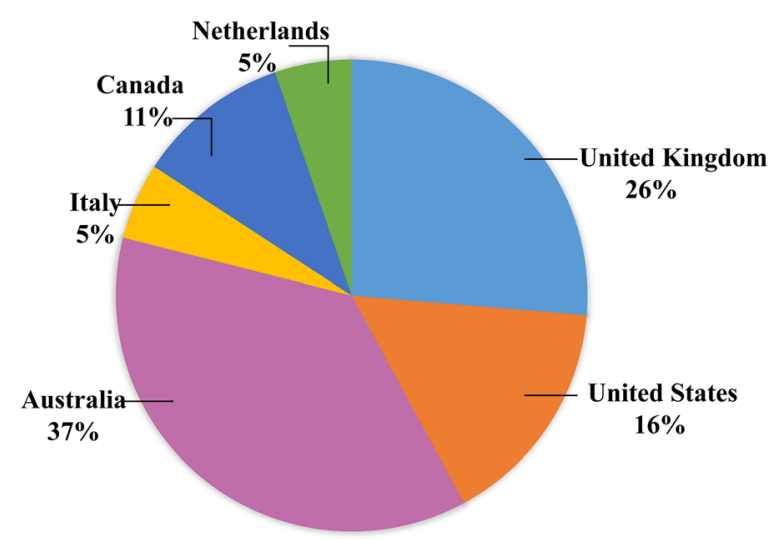

Fig. 5 Distribution of countries from the well-designed N-of-1 trials 


\section{DISCUSSION}

This study revealed several findings regarding the status of N-of- 1 trials in chronic pain management. First, the majority of the trials were conducted between 2004 and 2015; however, such trials have not been so popular in recent years. Second, N-of- 1 trials have accomplished great achievements in treating patients with refractory chronic pain. Third, conflicts are revealed between cost-benefit balance during the trial implementation. Fourth, N-of-1 trials are now mainly conducted in developed countries. Thus, how to break this territorial imbalance may be interesting for future inquiries.

\section{Development and Perspective of N-of-1 Trials in Pain Management}

The development of N-of- 1 trials in pain management has occurred alongside the overall history of other N-of- 1 trials [30]. Efficient and reliable statistical methods enabled large numbers of N-of- 1 trials for chronic pain management after 2014. The reasons for the slowing development nowadays are mainly due to the cost-benefit imbalance regarding time and effort. Regardless of the existing difficulties for implementation, N-of- 1 trials fit the concept of precision medicine and etiology diversity. As simple and reliable techniques have been introduced into $\mathrm{N}$-of- 1 procedures, efforts are in progress to facilitate their implementation.

It is important to collect validated information to discriminate the efficacy of treatments. Common parameters like visual analogue score are subjective and hence easily affected by the patient's mood. Nowadays, it is possible to adopt wireless wearable devices (e.g., bracelets, running shoe chips, etc.) for recording personal information (such as gait, walking frequency, etc.) to enhance the evaluation accuracy of pain treatment [31]. In this way, not only can patients with arthritis use the Trialist app to record visual analogue score regularly but they can also use the bracelet to record daily gait and cadence as objective indicators to assess their pain levels. In the future, it is possible that we could integrate wireless devices and smartphone apps into one system to conduct an $\mathrm{N}$-of-1 trial, hence liberating the clinicians and patients from the required time and effort. By that time, relevant data such as sleep status, exercise status, vital signs, and questionnaires filled in by the patient on the app could generate a daily report directly for follow-up.

\section{Profiles of N-of-1 Trials in Pain Management}

The N-of-1 trial plays an important role in chronic pain management at different levels. Firstly, physicians use N-of- 1 trials to improve prescribing for patients with chronic pain [14]. For example, some patients with osteoarthritis are uncertain about the efficacy after taking conventional painkillers. Their physicians could conduct an N-of-1 trial to compare two different treatments and determine the better one. In this way $\mathrm{N}$-of- 1 achieves a personalized treatment [32]. Secondly, N-of-1 trials could avoid drug abuse and drug misuse. Researchers found that patients in N-of-1 trials successfully reduced the long-term use of NSAIDs, which could minimize side effects [22]. Meanwhile, N-of- 1 trials offer access to evaluate whether patients benefit from expensive medication to treat pain [28]. Thirdly, N-of-1 trials also provide a testable strategy to figure out the best way for treating intractable chronic pain [33]. Physicians can compare a treatment plan with uncertain efficacy versus placebo, then determine whether the treatment plan is beneficial to the patient. Unlike the traditional RCTs, $\mathrm{N}$-of-1 trials can be carried out specifically for just one patient and the results are applicable to this specific patient [10]. After the trial, the patient can be provided with an individualized treatment plan [34]. Notably, although cancer pain is common in the pain clinic and often requires aggressive anti-pain treatments, according to our review, none of the N-of- 1 trials were conducted on this indication, which therefore requires more attention in the pain field. 


\section{Spectrum of N-of-1 Trials in Pain Management}

From the 19 trials recruited, treatments for the refractory chronic pain mainly focused on analgesics versus placebo, analgesics " $\mathrm{A}$ " versus analgesics " $\mathrm{B}$ " (not placebo), and N-of-1 trial versus usual care. To our knowledge, there are many evolutionary methods nowadays for pain management such as stem cell therapy [35] and neuromodulation [36]. Large numbers of clinical trials are needed to verify the efficacy of these new methods; however, then the majority of patients need to wait for a long time before the finalization of the RCTs. Indeed, N-of- 1 trials are good candidates to assess this translational process. First, one patient can complete one trial and multiple N-of- 1 trials can be integrated by using meta-analysis, which increases the overall evaluation efficiency. Second, N-of-1 trials avoid the long-term placebo treatment required in traditional RCTs and hence they fulfil the need for release from unbearable pain for the individuals.

The genetic heterogeneity is an intrinsic demand for N-of-1 trials [37]. Investigators are trying to adopt genetic data into more precise evidence-based medicine [38]. Ideally, patients will receive the most effective medicine for pain treatment after sequencing of their genetic background. We assume that the big data from genomics will reignite the interest in N-of-1 trials from both patients and clinicians.

\section{Conflicts Between Benefits and Effort in N- of-1 Trials in Pain Management}

Physicians and patients display different attitudes towards N-of- 1 trials [39]. Trial providers viewed N-of-1 trials as an exciting but likely threatening paradigm shift in the doctor-patient relationship. On the other hand, patients usually held a neutral attitude towards N-of-1 trials [39]. This ambiguous situation may add difficulties to carry out N-of-1 trials while treating patients with chronic pain. Moreover, as N-of-1 trial implementation is relatively cumbersome and involves multiple follow-ups and drug replacements, it will cause a higher withdrawal rate. The conflict between benefits and effort from N-of-1 has been increasing ever since its establishment. Regarding the time and effort consumed in N-of- 1 implementation, the Trialist app may solve this conflict with further optimization.

\section{Cohort Size of N-of-1 Trials}

As a result o the specific purpose and in-trial strategy for individual patients, the cohort size is relatively small in most N-of-1 trials [40]. The heterogeneity of treatment effects can be analyzed in N-of-1 studies that recruit multiple individuals [41]. In fact, some N-of- 1 trials can also be carried out on just one patient $[18,42]$. Thus, the cohort size of N-of- 1 trials is determined by the purpose of a study. Statistical methods are sufficient to calculate the accurate cohort size if heterogeneity analysis is the main purpose [43].

\section{Imbalance in Development of N-of-1 Trials in Different Countries}

When we focused on the diversity of the established N-of-1 trials in different countries, an imbalance emerged in N-of-1 implementation between developed and developing countries. Out of $19 \mathrm{~N}$-of- 1 trials related to pain management that we identified, all were conducted in developed countries. This is consistent with a systematic review in 2015 for the overall trials, which indicated that only 6 out of $131(4.5 \%)$ N-of-1 trials were conducted in developing countries [44].

The electronic medical recording system in some developing countries falls behind that in others [45]. N-of- 1 trials need the collection of abundant data from patients (such as the dosage of each medication, side effects after medication, etc.), which requires more manpower and material resources [22]. To address this problem, developed countries have begun to use mobile devices to support N-of-1 trials [20, 22, 23, 46]. However, this approach appears difficult to adopt in developing countries because of their poor economies [47]. The fact is, even if N-of-1 trials are carried out, the cumbersome 
procedures could also induce patient withdrawal in developing countries. Also, many doctors in developing countries do not have the time and energy to design individual treatment plans for each patient suffering from chronic pain [48]. In order to prevent medical disputes, they are more willing to use uniform treatment for every patient. These odds are responsible for the conflicts between developed and developing countries when carrying out N-of- 1 trials for chronic pain management. Of note, the three databases we searched are based on publications written in English. This may prevent articles published by some developing countries from being included. To this end, we searched the Chinese database CNKI using the strategy "pain, N-of-1 test"; however, no relevant publications were found. Only one N-of- 1 trial in Chinese was found, which was conducted to test the efficacy of traditional Chinese medicine.

Although health care systems vary in different countries, promoting N-of- 1 trials in developing countries is no doubt good for personalized medicine. Different countries have different population composition and different genetic backgrounds. The conclusions of N-of-1 trials conducted in developed countries may not be applicable to developing countries [49]. With the development of economies and decreasing costs of mobile apps, researchers believe that N-of-1 may provide a useful tool to seek the most efficacious and individualized therapy even in those developing countries.

\section{Comparison Between Classical RCTs and N-of-1 Trials}

The following differences have been noticed between classical RCTs and N-of-1 trials [50]. First, a classical RCT focuses on a subset of patients with more homogeneous disease to draw a conclusion that can be expanded to a broader population. On the contrary, the purpose of N-of- 1 is to concentrate on individualized medications for specific patients. Second, given that the incidence rate is too low in some rare diseases and the cohort size may not meet the criteria of classical RCTs, N-of-1 trials likely benefit patients with those rare disorders [42].
Furthermore, when the efficacy of new therapies remains unclear, N-of-1 trials can quickly determine benefits owing to the convenience of small cohort sizes [2, 11, 42, 44]. Third, for some symptom diagnoses like chronic pain, the etiology can vary widely. For those refractory cases with unclear causes, classical RCTs become extremely difficult. In this context, N-of- 1 trials can still be conducted on the basis of individualized and specific inclusion criteria.

Given the above, we conclude that the most significant advantage of N-of- 1 trials is that a single patient can become the subject of observation, and individualized therapy plans will be developed. Moreover, N-of-1 trials have a strict cross-control method, which requires that effective therapies for patients can be ultimately adopted. However, N-of-1 trials still have some disadvantages. For instance, to carry out an N-of-1 trial will be time consuming because of multiple follow-ups and drug alternations. Therefore, the average cost of N-of- 1 trails for a single patient is usually much higher than classical RCTs. Additionally, whether the conclusions from N-of- 1 trials can be consistently viewed alongside those from traditional RCTs needs to be clarified in future studies.

\section{CONCLUSIONS}

Existing studies reveal the complex status of $\mathrm{N}$-of- 1 in the health care activities, which draws a clear line between developed and developing countries for individual patients. Limitations in our study include the following: we just studied the published N-of-1 trials for chronic pain treatment; however, many $\mathrm{N}$-of- 1 cases in daily health care activity have not been reported, especially for those in developing countries. Our analysis might have bias based on the research strategies which relies on articles written in English. Nevertheless, the major findings in our study indicate the overall development of $\mathrm{N}$-of-1 trials in pain management, one of the most diverse diseases, as well as highlighting the previously unrecognized conflicts regarding their implementation worldwide. In the future, emerging simple and facilitated strategies to carry out N-of- 1 trials will improve the overall 
chronic pain treatment at the precision medication level.

\section{ACKNOWLEDGEMENTS}

Funding. National Natural Science Foundation of China to Fengxian Li (Grant Number: 81974192) provided funding for both the study and the journal's Rapid Service Fee.

Authorship. All named authors meet the International Committee of Medical Journal Editors (ICMJE) criteria for authorship for this article, take responsibility for the integrity of the work as a whole, and have given their approval for this version to be published.

Author Contributions. Wanying He, Zichan Cui and Yin Chen contribute to the statistical analysis. Fang Wang contributes to the drafting the manuscript. Fengxian Li contributes to the concept and design and drafting the manuscript.

Disclosures. Wanying $\mathrm{He}$, Zichan Cui, Yin Chen, Fang Wang and Fengxian Li have nothing to disclose.

Compliance with Ethics Guidelines. This article is based on previously conducted studies and does not contain any new studies with human participants or animals performed by any of the authors.

Data Availability. The datasets generated during and/or analyzed during the current study are available from the corresponding author on reasonable request.

Open Access. This article is licensed under a Creative Commons Attribution-NonCommercial 4.0 International License, which permits any non-commercial use, sharing, adaptation, distribution and reproduction in any medium or format, as long as you give appropriate credit to the original author(s) and the source, provide a link to the Creative Commons licence, and indicate if changes were made. The images or other third party material in this article are included in the article's Creative Commons licence, unless indicated otherwise in a credit line to the material. If material is not included in the article's Creative Commons licence and your intended use is not permitted by statutory regulation or exceeds the permitted use, you will need to obtain permission directly from the copyright holder. To view a copy of this licence, visit http://creativecommons.org/licenses/by$\mathrm{nc} / 4.0 /$.

\section{REFERENCES}

1. Watkins EA, Wollan PC, Melton LJ 3rd, Yawn BP. A population in pain: report from the Olmsted County health study. Pain Med. 2008;9(2):166-74.

2. March L, Irwig L, Schwarz J, Simpson J, Chock C, Brooks $\mathrm{P}$. $\mathrm{N}$ of 1 trials comparing a non-steroidal anti-inflammatory drug with paracetamol in osteoarthritis. BMJ. 1994;309(6961):1041-5 (discussion 1045-1046).

3. McQuay HJ, Carroll D, Jadad AR, et al. Dextromethorphan for the treatment of neuropathic pain: a double-blind randomised controlled crossover trial with integral N-of-1 design. Pain. 1994;59(1):127-33.

4. CONSORT extension for reporting N-of-1 trials (CENT) 2015 Statement. BMJ. 2016;355:i5381.

5. Paice JA, Penn RD, Kroin JS. Intrathecal octreotide for relief of intractable nonmalignant pain: 5-year experience with two cases. Neurosurgery. 1996;38(1):203-7.

6. Sheather-Reid RB, Cohen M. Efficacy of analgesics in chronic pain: a series of N-of- 1 studies. J Pain Symptom Manage. 1998;15(4):244-52.

7. Haines DR, Gaines SP. N of 1 randomised controlled trials of oral ketamine in patients with chronic pain. Pain. 1999;83(2):283-7.

8. Nikles CJ, Glasziou PP, Del Mar CB, Duggan CM, Clavarino A, Yelland MJ. Preliminary experiences with a single-patient trials service in general practice. Med J Aust. 2000;173(2):100-3.

9. Wegman AC, van der Windt DA, de Haan M, Deville WL, Fo CT, de Vries TP. Switching from NSAIDs to paracetamol: a series of $\mathrm{n}$ of 1 trials for individual patients with osteoarthritis. Ann Rheum Dis. 2003;62(12):1156-61. 
10. Margolis A, Giuliano C. Making the switch: from case studies to N-of-1 trials. Epilepsy Behav Rep. 2019;12: 100336.

11. Green AL, Shad A, Watson R, Nandi D, Yianni J, Aziz TZ. N-of-1 trials for assessing the efficacy of deep brain stimulation in neuropathic pain. Neuromodulation. 2004;7(2):76-81.

12. Pope JE, Prashker M, Anderson J. The efficacy and cost effectiveness of $\mathrm{N}$ of 1 studies with diclofenac compared to standard treatment with nonsteroidal antiinflammatory drugs in osteoarthritis. J Rheumatol. 2004;31(1):140-9.

13. Nikles CJ, Yelland M, Glasziou PP, Del Mar C. Do individualized medication effectiveness tests (n-of1 trials) change clinical decisions about which drugs to use for osteoarthritis and chronic pain? Am J Ther. 2005;12(1):92-7.

14. Nikles CJ, Clavarino AM, Del Mar CB. Using N-of-1 trials as a clinical tool to improve prescribing. Br J General Pract. 2005;55(512):175-80.

15. Huber AM, Tomlinson GA, Koren G, Feldman BM. Amitriptyline to relieve pain in juvenile idiopathic arthritis: a pilot study using Bayesian metaanalysis of multiple N-of-1 clinical trials. J Rheumatol. 2007;34(5):1125-32.

16. Yelland MJ, Nikles CJ, McNairn N, Del Mar CB, Schluter PJ, Brown RM. Celecoxib compared with sustained-release paracetamol for osteoarthritis: a series of n-of-1 trials. Rheumatology (Oxford). 2007;46(1):135-40.

17. Yelland MJ, Poulos CJ, Pillans PI, et al. N-of-1 randomized trials to assess the efficacy of gabapentin for chronic neuropathic pain. Pain Med. 2009;10(4):754-61.

18. Nixdorf DR, Sobieh R, Gierthmuhlen J. Using an n-of-1 trial to assist in clinical decision making for patients with orofacial pain. J Am Dent Assoc. 2012;143(3):259-61.

19. Germini F, Coerezza A, Andreinetti L, et al. N-of-1 randomized trials of ultra-micronized palmitoylethanolamide in older patients with chronic pain. Drugs Aging. 2017;34(12):941-52.

20. Odineal DD, Marois MT, Ward D, et al. Effect of mobile device-assisted N-of-1 trial participation on analgesic prescribing for chronic pain: randomized controlled trial. J Gen Intern Med. 2020;35(1): 102-11.

21. Lee RR, Shoop-Worrall S, Rashid A, Thomson W, Cordingley L. "Asking too much?": randomized N-of-1 trial exploring patient preferences and measurement reactivity to frequent use of remote multidimensional pain assessments in children and young people with juvenile idiopathic arthritis. J Med Internet Res. 2020;22(1): e14503.

22. Kravitz RL, Schmid CH, Marois M, et al. Effect of mobile device-supported single-patient multicrossover trials on treatment of chronic musculoskeletal pain: a randomized clinical trial. JAMA Intern Med. 2018;178(10):1368-77.

23. Whitney RL, Ward DH, Marois MT, Schmid CH, Sim I, Kravitz RL. Patient perceptions of their own data in mHealth technology-enabled N-of-1 trials for chronic pain: qualitative study. JMIR Mhealth Uhealth. 2018;6(10): e10291.

24. Notcutt W, Price M, Miller R, et al. Initial experiences with medicinal extracts of cannabis for chronic pain: results from 34 "N of 1 " studies. Anaesthesia. 2004;59(5):440-52.

25. Guyatt G, Sackett D, Taylor DW, Chong J, Roberts R, Pugsley S. Determining optimal therapy-randomized trials in individual patients. N Engl J Med. 1986;314(14):889-92.

26. Marcucci M, Germini F, Coerezza A, et al. Efficacy of ultra-micronized palmitoylethanolamide (um-PEA) in geriatric patients with chronic pain: study protocol for a series of N-of-1 randomized trials. Trials. 2016;17:369.

27. Scuffham PA, Nikles J, Mitchell GK, et al. Using $\mathrm{N}$-of-1 trials to improve patient management and save costs. J Gen Intern Med. 2010;25(9):906-13.

28. Scuffham PA, Yelland MJ, Nikles J, Pietrzak E, Wilkinson D. Are N-of-1 trials an economically viable option to improve access to selected high cost medications? Aust Experience Value Health. 2008;11(1):97-109.

29. Martin R, Vogtle L, Gilliam F, Faught E. Health-related quality of life in senior adults with epilepsy: what we know from randomized clinical trials and suggestions for future research. Epilepsy Behav. 2003;4(6):626-34.

30. Mirza RD, Punja S, Vohra S, Guyatt G. The history and development of N-of-1 trials. J R Soc Med. 2017;110(8):330-40.

31. O'Brien N, Philpott-Morgan S, Dixon D. Using impairment and cognitions to predict walking in osteoarthritis: a series of n-of-1 studies with an individually tailored, data-driven intervention. Br J Health Psychol. 2016;21(1):52-70.

32. Schork NJ. Personalized medicine: time for oneperson trials. Nature. 2015;520(7549):609-11. 
33. Nixdorf DR, Sobieh R, Gierthmühlen J. Using an $\mathrm{N}$-of-1 trial to assist in clinical decision making for patients with orofacial pain. J Am Dent Assoc. 2012;143(3):259-61.

34. Clough AJ, Hilmer SN, Naismith SL, Kardell LD, Gnjidic D. N-of-1 trials for assessing the effects of deprescribing medications on short-term clinical outcomes in older adults: a systematic review. J Clin Epidemiol. 2018;93:112-9.

35. Chakravarthy K, Chen Y, He C, Christo PJ. Stem cell therapy for chronic pain management: review of uses, advances, and adverse effects. Pain Physician. 2017;20(4):293-305.

36. Fishman MA, Antony A, Esposito M, Deer T, Levy R. The evolution of neuromodulation in the treatment of chronic pain: forward-looking perspectives. Pain Med. 2019;20(Suppl 1):S58-68.

37. Lillie EO, Patay B, Diamant J, Issell B, Topol EJ, Schork NJ. The N-of-1 clinical trial: the ultimate strategy for individualizing medicine? Pers Med. 2011;8(2):161-73.

38. Ioannidis JPA, Khoury MJ. Evidence-based medicine and big genomic data. Hum Mol Genet. 2018;27(R1):R2-7.

39. Kravitz RL, Paterniti DA, Hay MC, et al. Marketing therapeutic precision: potential facilitators and barriers to adoption of N-of- 1 trials. Contemp Clin Trials. 2009;30(5):436-45.

40. Li J, Gao W, Punja S, et al. Reporting quality of N-of-1 trials published between 1985 and 2013: a systematic review. J Clin Epidemiol. 2016;76:57-64.

41. Raman G, Balk EM, Lai L, et al. Evaluation of person-level heterogeneity of treatment effects in published multiperson N-of-1 studies: systematic review and reanalysis. BMJ Open. 2018;8(5): $\mathrm{e} 017641$.
42. Kim J, Hu C, Moufawad El Achkar C, et al. Patientcustomized oligonucleotide therapy for a rare genetic disease. N Eng J Med. 2019;381(17): $1644-52$.

43. Senn S. Sample size considerations for N-of-1 trials. Stat Methods Med Res. 2019;28(2):372-83.

44. Alemayehu C, Nikles J, Mitchell G. N-of-1 trials in the clinical care of patients in developing countries: a systematic review. Trials. 2018;19(1):246.

45. Katurura MC, Cilliers L. Electronic health record system in the public health care sector of South Africa: a systematic literature review. Afr J Prim Health Care Fam Med. 2018;10(1):e1-8.

46. Barr C, Marois M, Sim I, et al. The PREEMPT studyevaluating smartphone-assisted N-of-1 trials in patients with chronic pain: study protocol for a randomized controlled trial. Trials. 2015;16:67.

47. Kruse C, Betancourt J, Ortiz S, et al. Barriers to the use of mobile health in improving health outcomes in developing countries: systematic review. J Med Internet Res. 2019;21(10): e13263.

48. Sa KN, Moreira L, Baptista AF, et al. Prevalence of chronic pain in developing countries: systematic review and meta-analysis. Pain Rep. 2019;4(6): e779.

49. Gabler NB, Duan N, Vohra S, Kravitz RL. N-of-1 trials in the medical literature: a systematic review. Med Care. 2011;49(8):761-8.

50. Bradbury J, Avila C, Grace S. Practice-based research in complementary medicine: could N-of- 1 trials become the new gold standard? Healthcare (Basel). 2020;8(1). 